\title{
Clinical manifestations of human coronavirus NL63 infection in children in Taiwan
}

\author{
Ping-Sheng Wu $\cdot$ Luan-Yin Chang $\cdot$ B. Berkhout • \\ L. van der Hoek • Chun-Yi Lu • Chuan-Liang Kao • \\ Ping-Ing Lee • Pei-Lan Shao • Chin-Yun Lee • \\ Fu-Yuan Huang $\cdot$ Li-Min Huang
}

Received: 14 November 2006 / Accepted: 18 January 2007 / Published online: 13 February 2007

(C) Springer-Verlag 2007

\begin{abstract}
Human coronavirus NL63 (HCoV-NL63) is a global respiratory tract pathogen; however, the epidemiology of this virus in subtropical area is not well known. To evaluate the epidemics and disease spectrum of $\mathrm{HCoV}$ NL63 infection in children in Taiwan, we prospectively screened children admitted to the hospital with respiratory tract infection from May 2004 to April 2005. Every enrolled child had a nasopharyngeal aspirate (NPA) sample taken. Quantitative RT-PCR was used to detect $1 \mathrm{~b}$ gene of HCoV-NL63. A total of 539 NPAs were collected. Seven
\end{abstract}

\author{
P.-S. Wu \\ Department of Pediatrics, \\ Buddhist Tzu Chi General Hospital, Taipei Branch, \\ Taipei, Taiwan \\ L.-Y. Chang • C.-Y. Lu • P.-I. Lee • P.-L. Shao • C.-Y. Lee $•$ \\ L.-M. Huang $(\bowtie)$ \\ Department of Pediatrics, \\ National Taiwan University Hospital, \\ 7, Chung-Shan South Road, \\ Taipei 100, Taiwan \\ e-mail: 1mhuang@ha.mc.ntu.edu.tw \\ C.-L. Kao \\ Department of Laboratory Medicine, \\ National Taiwan University Hospital, \\ Taipei, Taiwan \\ F.-Y. Huang \\ Department of Pediatrics, \\ Taipei Mackay Memorial Hospital, \\ Taipei, Taiwan \\ B. Berkhout $\cdot$ L. van der Hoek \\ Department of Human Retrovirology, Academic Medical Center, \\ University of Amsterdam, \\ Amsterdam, The Netherlands
}

(1.3\%) were positive for HCoV-NL63. All cases were boys younger than 3 years of age and most cases occurred in autumn. Co-infection with other pathogens was observed in three cases. The most common symptoms/signs of HCoVNL63 infection were cough, fever, and inspiratory stridor. HCoV-NL63 was the most common pathogen (14.7\%) in children with croup and was the cause of three cases of croup in October. The odds ratio of croup in children infected with HCoV-NL63 was 43.4 (95\% CI 8.1 233.1). In conclusion, HCoV-NL63 is an important respiratory tract pathogen as the main cause in children admitted to the hospital in Taiwan.

Keywords Coronavirus infections .

Respiratory tract infections · Croup · Taiwan

\section{Introduction}

Respiratory tract infection (RTI) occurs frequently in young children, immuno-compromised persons and the elderly and often leads to hospitalization. Coronaviridae have been the focus of attention since the SARS outbreak in 2003. Human coronavirus NL63 (HCoV-NL63) is the fourth human coronavirus identified and is mostly related to HCoV-229E with $65 \%$ sequence identity [13]. HCoVNL63 has been shown to be a worldwide pathogen responsible for upper and lower RTI $[1-3,6,9,11,12]$. This virus could be detected in $2-8.8 \%$ of nasopharyngeal aspirates (NPA) from patients with respiratory tract diseases $[1,6]$. Infection with HCoV-NL63 occurs mainly in winter seasons in temperate countries, and peaks in summer in Hong Kong [3]. This study is aimed to understand the seasonal distribution and clinical manifestations of $\mathrm{HCoV}$ NL63 infection in children in Taiwan. 


\section{Materials and methods}

Study population

From May 2004 to April 2005, we screened HCoV-NL63 in NPA specimens collected from children under 15 years of age admitted to National Taiwan University Hospital (NTUH). Those recruited were suffering from pneumonia, acute bronchiolitis, acute bronchitis, croup, acute otitis media, acute paranasal sinusitis, acute tonsillitis, acute conjunctivitis, or young infant fever. This study excluded all cases with the diagnosis of herpangina, hand-foot-mouth disease and herpetic gingivostomatitis. We reviewed the medical charts and chest X-rays of children with positive NPA specimens. The clinical characteristics of HCoV-NL63 infection were compared with those caused by respiratory syncytial virus (RSV). This study was approved by the ethical committee of National Taiwan University Hospital.

\section{Laboratory examination}

The NPA specimens were subjected to virus isolation using five cell lines (human embryonic lung fibroblast, HEp-2, RD, MK-2, MDCK), and antigen detection of RSV and parainfluenza viruses was performed by the indirect fluorescent assay (Dako, USA). Real time quantitative RTPCR was used to detect human metapneumovirus and HCoV-NL63. The oligomers for detecting $\mathrm{N}$ gene sequences of HCoV-NL63 are: forward primer 5'-CTAGTTCTTC TGGTACTTCCACTCC-3', reverse primer 5'-TCTGGTAG GAACACGCTTCCAA-3, and the TaqMan probe (Roche) FAM-5'-TAAGCCTCTTTCTCAACCCAGGGC-3' TAMRA. The viral RNA was isolated using viral RNA Mini kit (Qiagen, Hilden, Germany). The viral load was quantified by real-time PCR analysis with a LightCycler
(Roche, Mannheim, Germany). Positive samples were further confirmed by RT-PCR for $1 \mathrm{~b}$ gene (forward primer 5'-GTGATGCATATGCTAATTTG-3', reverse primer 5'CTCTTGCAGGTATAATCCTA-3') and by sequencing of amplicons.

Phylogenetic analysis

PCR-amplified products of partial spike gene (654 bp) were sequenced and then aligned with sequences of other strains using DNAMAN, version 5.2.2. Other reference sequences (DQ445911, DQ445912, AY518894, AY567487) of spike gene of HCoV-NL63 were obtained in GenBank (http:// www.ncbi.nlm.nih.gov/Genbank/index.html). HCoV-229E (DQ243986) is used as an outgroup.

Statistical analysis

Chi-square and Fisher's exact test were used to analyse categorical variables such as the percentage of the symptoms and signs of patients with HCoV-NL63 compared to those with respiratory syncytial virus infection. MannWhitney $U$ test was used to compare the difference of HCoV-NL63 viral load between single infection and coinfection groups. A significant statistical result is achieved if the $p$ value $<0.05$.

\section{Results}

A total of 539 NPA samples were screened for HCoV-NL63 from April 2004 to May 2005. There were 190 NPA samples collected between February and April, 106 between May and July, 121 between August and October, and 122 between November and January. Seven samples
Fig. 1 Positive real time RTPCR rate of HCoV-NL63 from May 2004 to April 2005

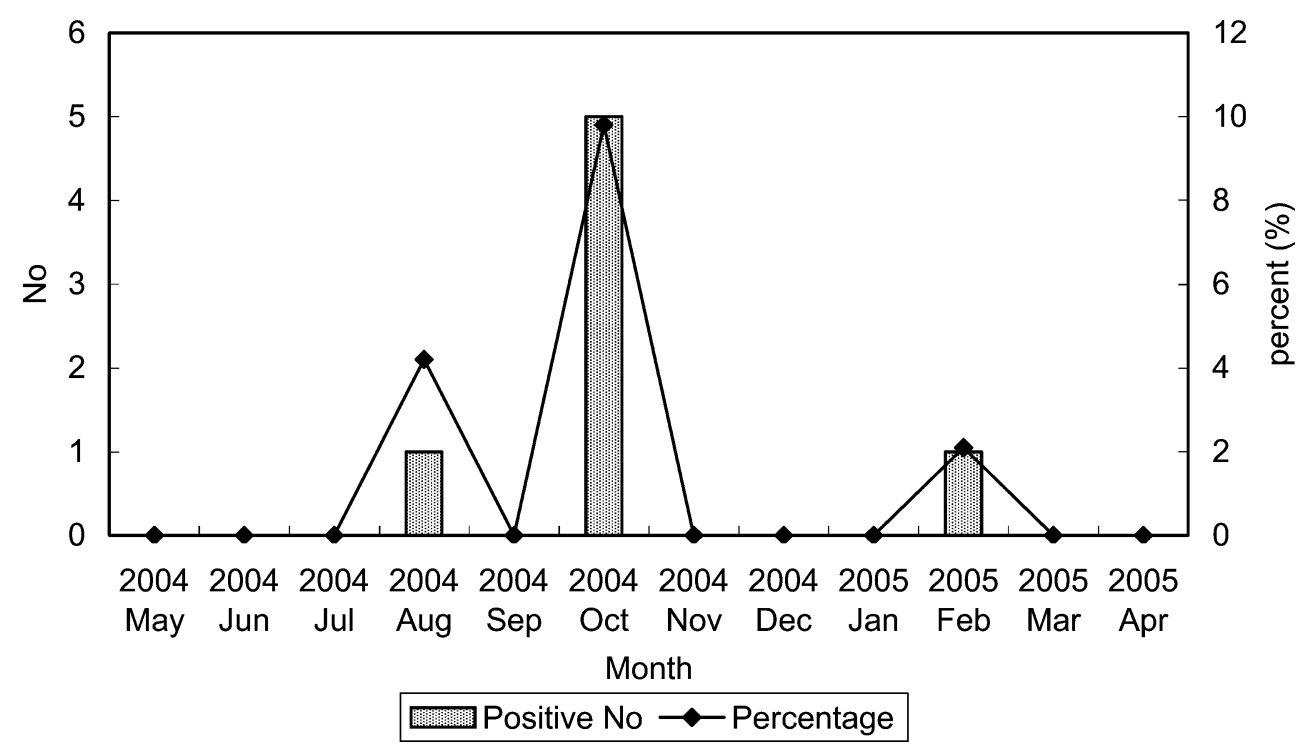


were positive for HCoV-NL63. Among the positive samples, one was collected in August, five in October, and one in February. The positive detection rate was $1.3 \%$ for this year. The positive rates of HCoV-NL63 per month were between 0 and $9.8 \%$ (Fig. 1). The most prevalent season of HCoV-NL63 infection was autumn in Taiwan (5.0\%). During the study period, 187 NPA samples yielded at least one pathogen by all diagnostic methods. Thus, HCoV-NL63 was responsible for $3.7 \%$ of childhood viral respiratory tract infections which were detectable by our methodology.

The demographic and clinical manifestations are shown in Table 1. The median age of the seven children infected with HCoV-NL63 was 1 year and 10 months (range from 8 months to 2 years 10 months) and all infected subjects were male. The positive samples were taken from 2 to 6 days after disease onset. Viral loads in NPA ranged from 50 to 9,760 RNA copies/ $\mu$ l. Partial sequences of two positive NPA specimens (nos. 567 and 754) with higher HCoV-NL63 copy number were determined, and aligned with other available spike gene sequence worldwide (Fig. 2). No underlying disease was apparent in these patients, except for one child with biliary atresia who had received orthotic liver transplantation and was treated with FK-506. Four cases had family members with respiratory tract infection in the preceding week.

The hospitalization durations of these seven children ranged from 2 to 5 days. The clinical symptoms were fever $(71 \%)$, cough $(100 \%)$, coryza $(43 \%)$, dyspnea $(43 \%)$, and abdominal distension or diarrhea (43\%). Fever lasted for 2 to 6 days. The clinical signs included stridor (71\%), wheezing (29\%), and rales/rhonchi (29\%).

The median white cell count was $16,200 / \mathrm{mm}^{3}$ (range from 8,260 to $28,150 / \mathrm{mm}^{3}$ ), with $45-79 \%$ neutrophils. Levels of C-reactive protein were between 0.03 and $4.86 \mathrm{mg} / \mathrm{dL}$. All HCoV-NL63 positive patients had abnormal findings on chest X-ray examination, including four cases with neck steeple sign, two cases with increased infiltration over lung fields, and one case with pneumonia patch. The major diagnoses of children with HCoV-NL63 infection were croup in five cases (including one case diagnosed with acute bronchiolitis concurrently) and pneumonia in two cases.

We made a comparison between the illnesses caused by HCoV-NL63 and RSV (Table 2). There was no statistically significant difference in the rates of fever, cough, coryza, dyspnea, diarrhea or wheezing. However, there were more cases with stridor in children infected with HCoV-NL63 $(P<0.01)$, while rhonchi and rales were more common in children infected with RSV $(P<0.01)$.

There were a total of 34 cases of croup during the study period. HCoV-NL63 was the most common pathogen, responsible for $14.7 \%$ of the croup cases. The odds ratio

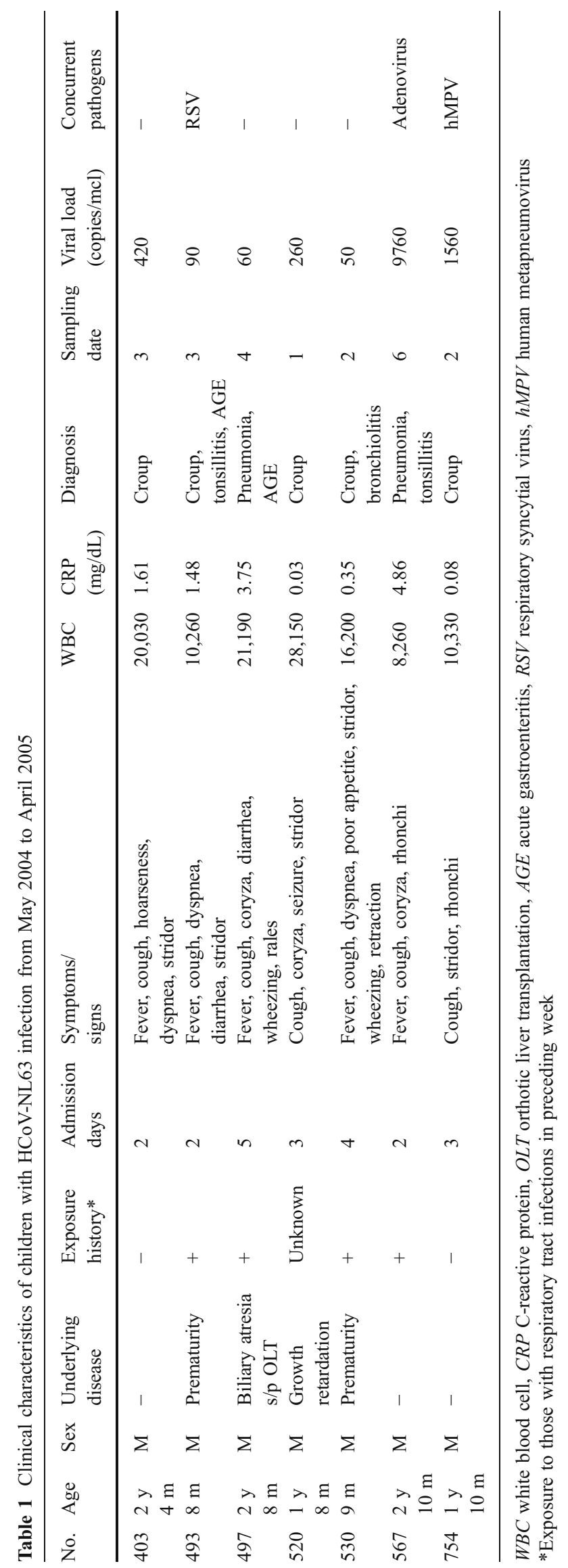




\subsection{5}
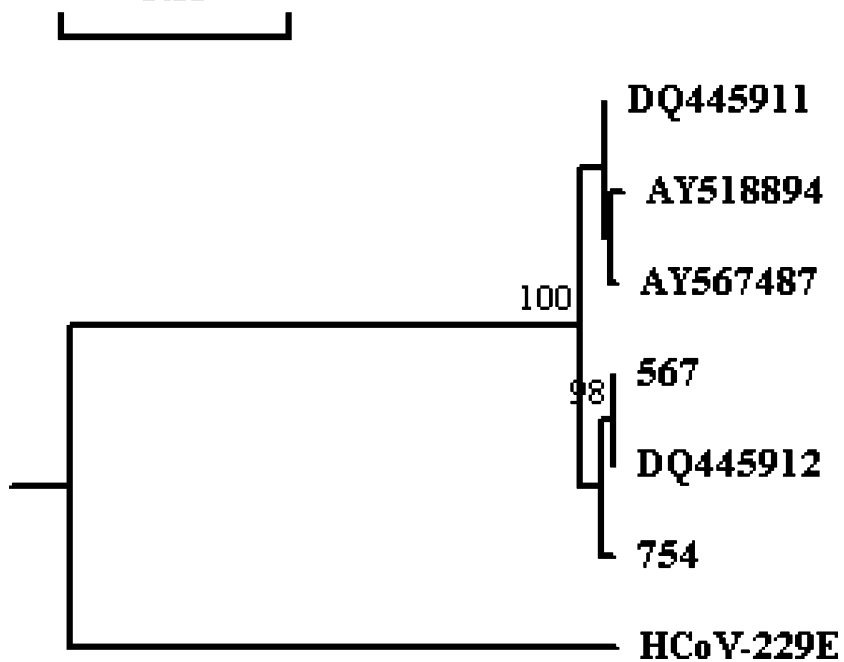

Fig. 2 Phylogenetic analysis of partial spike gene region (654 bp) of HCoV-NL63. Phylogenetic trees were constructed by the neighborjoining method, and bootstrap values were determined by 1,000 replicates in DNAMAN, version 5.2.2. Two available sequences in Taiwan (nos. 567 and 754) and other reference sequences obtained in GenBank (DQ445911, DQ445912, AY518894, AY567487) were included. HCoV-229E (DQ243986) is used as an outgroup. Genetic sequences from five other NPA specimens could not be obtained due to lower PCR product amplification

of croup in children infected with HCoV-NL63 was 43.4 times higher than in children without HCoV-NL63 infection (95\% CI 8.1 233.1). Other causes of croup were parainfluenza type $3(11.8 \%)$, parainfluenza type $1(8.8 \%)$ and influenza B virus $(8.8 \%)$. Of note was that no pathogens could be found in 19 children suffering from croup. The age distribution, clinical severity, laboratory data and hospitalization course of viral croup were indistinguishable for patients infected with HCoV-NL63 or one of the other viruses.

\section{Discussion}

HCoV-NL63 is the fourth human coronavirus identified. The clinical significance of this new virus is gradually being revealed. Apparently, HCoV-NL63 is largely a respiratory tract pathogen, capable of inducing upper and lower RTI, with symptoms considered to be more severe than those caused by $\mathrm{HCoV} 229 \mathrm{E}$ or $\mathrm{HCoV}$ OC43 [1]. In this study, we prospectively studied the role of HCoV-NL63 in Taiwanese children hospitalized due to respiratory tract infection. Among the 539 patients, seven cases of HCoVNL63 infection were identified. Proportionally, $1.3 \%$ of children with RTI were infected with HCoV-NL63 in the study period. This rate is lower than those reported for other countries, which ranged from $2-8.8 \%[1-3,6,9,11,12]$. However, this study recruited only admission cases and would miss children with mild symptoms that were not admitted. Indeed, HCoV-NL63 may be more prevalent in the out-patient than the in-patient group [14]. The majority of infected children were under 3 years old and all male in gender, which is similar to what has been reported previously $[1-3,6,9,11,12]$. Dual infections were frequent (43\%) in this study. Van der Hoek et al. [14] described a significant difference between the HCoV-NL63 viral loads of singly infected and co-infection groups; however, we did not have similar observations in this study $(p=0.229)$. Whether dual infection would lead to more severe clinical manifestations needs further study.

We have made a summary of the published data on HCoV-NL63 (Table 3). In the present study, HCoV-NL63 was detected using quantitative RT-PCR targeting $\mathrm{N}$ gene, while previous studies targeted ORF $1 \mathrm{a}$ or $1 \mathrm{~b}$ by conventional RT-PCR. The seasonality in the present study was in autumn, while in temperate countries it is winter $[2,6,9$, 11, 12], and summer in Hong Kong [3]. Phylogenetic analysis of partial spike gene showed two lineages of HCoV-NL63 in the world; however, our study could not answer whether there was cocirculation of these two variants in 2004 and 2005 in Taiwan due to the small number of positive cases.

The clinical symptoms/signs in children infected with HCoV-NL63 were quite similar to those with other virus infection. One striking finding was the frequent occurrence of stridor and diagnosis of croup in patients with $\mathrm{HCoV}$ NL63 infection. Previous studies found that acute bron-
Table 2 Comparisons of clinical presentation among children with HCoV-NL63 and respiratory syncytial virus (RSV) infection

${ }^{*} P$ values are from Fisher's exact probability test

\begin{tabular}{llll}
\hline Clinical symptoms and signs & HCoV-NL63 $n=7(\%)$ & RSV $n=61(\%)$ & $P$ value* \\
\hline Fever & $5(71)$ & $44(72)$ & 0.97 \\
Coryza & $3(43)$ & $45(74)$ & 0.09 \\
Cough & $7(100)$ & $60(98)$ & 0.73 \\
Dyspnea & $3(43)$ & $37(61)$ & 0.36 \\
Diarrhea & $2(29)$ & $13(21)$ & 0.66 \\
Stridor & $5(71)$ & $1(2)$ & $<0.01$ \\
Wheezing & $2(29)$ & $27(69)$ & 0.42 \\
Rhonchi/rales & $3(43)$ & $56(92)$ & $<0.01$ \\
Retractions & $1(14)$ & $31(51)$ & 0.07 \\
\hline
\end{tabular}


Table 3 International trends of HCoV-NL63 infection

\begin{tabular}{|c|c|c|c|c|c|c|}
\hline & France [12] & Belgium [9] & Canada [2] & Australia [1] & USA [6] & $\begin{array}{l}\text { Taiwan (Wu et al., } \\
\text { present study) }\end{array}$ \\
\hline $\begin{array}{l}\text { Seasonal } \\
\text { distribution }\end{array}$ & Peak in Feb 2003 & Jan/Feb 2003 & $\begin{array}{l}\text { Peak in Mar } \\
2003\end{array}$ & Peak in mid-winter & Most in first 10 weeks & Peak in Oct 2004 \\
\hline Method & RT-PCR (N, S gene) & $\begin{array}{l}\text { RT-PCR (N } \\
\text { gene, ORF 1a, } \\
\text { ORF1b) }\end{array}$ & $\begin{array}{l}\text { RT-PCR } \\
\text { (N gene, } \\
\text { ORF 1a) }\end{array}$ & $\begin{array}{l}\text { RT-PCR (ORF 1a, } \\
\text { 1b) }\end{array}$ & RT-PCR (ORF 1a) & $\begin{array}{l}\text { Real-time PCR (N gene, } \\
\text { ORF 1b) }\end{array}$ \\
\hline Population & In-patients & In-patients & $\begin{array}{l}\text { Out- and in- } \\
\text { patients }\end{array}$ & Out- and in-patients & In-patients, prematurity & In-patients \\
\hline Incidence & $9.3 \%$ & $2.3 \%$ & $2.1 \%$ & $2.0 \%$ & $8.8 \%$ & $1.3 \%$ \\
\hline $\begin{array}{l}\text { Susceptible } \\
\text { population }\end{array}$ & $\begin{array}{l}18 \text { cases under } \\
2 \text { years }\end{array}$ & $\begin{array}{l}6 \text { cases under } \\
2 \text { years }\end{array}$ & $\begin{array}{l}22 \text { cases } \\
\text { under } 2 \text { years }\end{array}$ & $\begin{array}{l}14 \text { cases under } 2 \text { y } \\
4 \mathrm{~m}\end{array}$ & 50 cases under 1 year & 7 cases under 3 years \\
\hline $\begin{array}{l}\text { Co- } \\
\text { infection } \\
\text { rate }\end{array}$ & - & - & - & $38 \%$ & $11.8 \%$ & $42.8 \%$ \\
\hline Diagnosis & $\begin{array}{l}\text { Bronchiolitis, } \\
\text { pneumonia, AGE, } \\
\text { otitis, pharyngitis, } \\
\text { Conjunctivitis }\end{array}$ & $\begin{array}{l}3 \text { URTI and } 4 \\
\text { LRTI }\end{array}$ & $\begin{array}{l}\text { Bronchiolitis, } \\
\text { croup, } \\
\text { asthma } \\
\text { exacerbation }\end{array}$ & $\begin{array}{l}\text { Acute bronchiolitis, } \\
\text { croup, pneumonia }\end{array}$ & - & $\begin{array}{l}\text { Croup, pneumonia, } \\
\text { AGE, bronchiolitis }\end{array}$ \\
\hline $\begin{array}{l}\text { Clinical } \\
\text { symptoms } \\
\text { or signs }\end{array}$ & Fever, rhinorrhea & $\begin{array}{l}\text { Fever, cough, } \\
\text { wheezing, } \\
\text { respiratory } \\
\text { distress, } \\
\text { diarrhea }\end{array}$ & $\begin{array}{l}\text { Fever, cough, } \\
\text { dyspnea, } \\
\text { desaturation }\end{array}$ & $\begin{array}{l}\text { Fever, cough, } \\
\text { coryza, respiratory } \\
\text { distress, wheezing, } \\
\text { rales, stridor }\end{array}$ & $\begin{array}{l}\text { Fever, cough, } \\
\text { rhinorrhea, tachypnea, } \\
\text { rhonchi/rales, retractions, } \\
\text { wheezing, stridor }\end{array}$ & $\begin{array}{l}\text { Fever, cough, coryza, } \\
\text { dyspnea, GI problems, } \\
\text { stridor, wheezing, rales / } \\
\text { rhonchi }\end{array}$ \\
\hline $\begin{array}{l}\text { Image } \\
\text { study }\end{array}$ & - & - & $\begin{array}{l}\text { Abnormal } \\
\text { CXR 92\% }\end{array}$ & $\begin{array}{l}\text { Abnormal CXR } \\
56 \%\end{array}$ & Abnormal CXR 65.8\% & Abnormal CXR 100\% \\
\hline
\end{tabular}

$A G E$ acute gastroenteritis, URTI upper respiratory tract infection, LRTI lower respiratory tract infection, CXR chest X-ray

chiolitis was a common diagnosis in children with $\mathrm{HCoV}$ NL63 infection $(38 \sim 67 \%)$. The relationship between Kawasaki disease and HCoV-NL63 was suggested in one study [7], but could not be confirmed thus far in other studies [5, 10]. No children with HCoV-NL63 infection were suffering from Kawasaki disease in this case series.

It is interesting to note that croup is a major clinical illness caused by HCoV-NL63. Viral croup accounts for
Fig. 3 The incidence of croup and viral epidemics in NTUH from May 2004 to April 2005

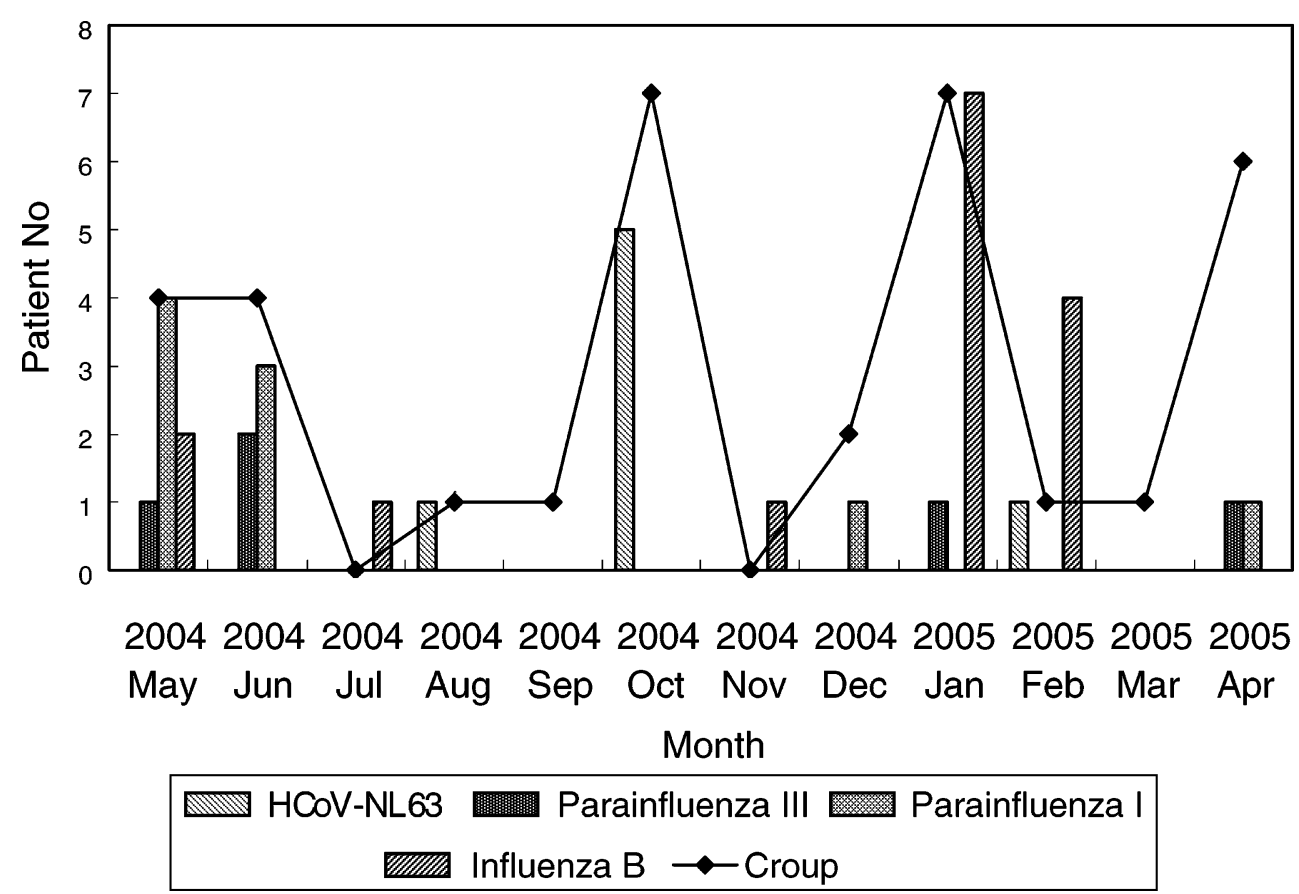


$15 \%$ of respiratory tract infections in children [4] and 41,000 hospitalizations annually in the United States [8]. The highest incidence, three to five cases per 100 children, occurs during the second year of life [8]. The etiology of viral croup includes parainfluenza types 1 to 3 , influenza A and $\mathrm{B}$, adenovirus, RSV, rhinovirus, measles and Mycoplasma pneumoniae. However, no pathogen can be defined in $36 \%$ to $62 \%$ of croup cases [8]. There were 34 cases of croup in this study and five (14.7\%) were caused by HCoVNL63.

The role of HCoV-NL63 in croup has also been revealed by a recent European study [14]. We regard HCoV-NL63 to be a real pathogen of croup because of the overlapping age and seasonality of croup and virus infection and $\mathrm{HCoV}$ NL63 being the only identified pathogen in three cases. During the study period, four clusters of croup were noted. Three of the four clusters were caused by parainfluenza type 1 and type 3, HCoV-NL63, and influenza B, respectively, while no pathogen could be found in fourth cluster (Fig. 3).

\section{References}

1. Arden KE, Nissen MD, Sloots TP, Mackay IM (2005) New human coronavirus, HCoV-NL63, associated with severe lower respiratory tract disease in Australia. J Med Virol 75(3):455-462

2. Bastien N, Anderson K, Hart L, Van Caeseele P, Brandt K, Milley D, Hatchette T, Weiss EC, Li Y (2005) Human coronavirus NL63 infection in Canada. J Infect Dis 191(4):503-506

3. Chiu SS, Chan KH, Chu KW, Kwan SW, Guan Y, Poon LL, Peiris JS (2005) Human coronavirus NL63 infection and other coronavirus infections in children hospitalized with acute respiratory disease in Hong Kong, China. Clin Infect Dis 40(12):1721-1729
4. Denny FW, Murphy TF, Clyde WA, Collier AM, Henderson FW (1983) Croup: an 11-year study in a pediatric practice. Pediatrics 71(6):871-876

5. Ebihara T, Endo R, Ma X, Ishiguro N, Kikuta H (2005) Lack of association between New Haven coronavirus and Kawasaki disease. J Infect Dis 192(2):351-352

6. Esper F, Weibel C, Ferguson D, Landry ML, Kahn JS (2005) Evidence of a novel human coronavirus that is associated with respiratory tract disease in infants and young children. J Infect Dis 191(4):492-498

7. Esper F, Shapiro ED, Weibel C, Ferguson D, Landry ML, Kahn JS (2005) Association between a novel human coronavirus and Kawasaki disease. J Infect Dis 191(4):499-502

8. Marx A, Török TJ, Holman RC, Clarke MJ, Anderson LJ (1997) Pediatric hospitalizations for croup (laryngotracheobronchitis): biennial increases associated with human parainfluenza virus 1 epidemics. J Infect Dis 176(6):1423-1427

9. Moes E, Vijgen L, Keyaerts E, Zlateva K, Li S, Maes P, Pyrc K, Berkhout B, van der Hoek L, Van Ranst M (2005) A novel pancoronavirus RT-PCR assay: frequent detection of human coronavirus NL63 in children hospitalized with respiratory tract infections in Belgium. BMC Infect Dis 5(1):6

10. Shimizu C, Shike H, Baker SC, Garcia F, van der Hoek L, Kuijpers TW, Reed SL, Rowley AH, Shulman ST, Talbot HK, Williams JV, Burns JC (2005) Human coronavirus NL63 is not detected in the respiratory tracts of children with acute Kawasaki disease. J Infect Dis 192(10):1767-1771

11. Suzuki A, Okamoto M, Ohmi A, Watanabe O, Miyabayashi S, Nishimura H (2005) Detection of human coronavirus-NL63 in children in Japan. Pediatr Infect Dis J 24(7):645-646

12. Vabret A, Mourez T, Dina J, van der Hoek L, Gouarin S, Petitjean J, Brouard J, Freymuth F (2005) Human coronavirus NL63, France. Emerg Infect Dis 11(8):1225-1229

13. van der Hoek L, Pyrc K, Jebbink MF, Vermeulen-Oost W, Berkhout RJ, Wolthers KC, Wertheim-van Dillen PM, Kaandorp J, Spaargaren J, Berkhout B (2004) Identification of a new human coronavirus. Nat Med 10(4):368-373

14. van der Hoek L, Sure K, Ihorst G, Stang A, Pyrc K, Jebbink MF, Petersen G, Forster J, Berkhout B, Uberla K (2005) Croup is associated with the novel coronavirus NL63. PLoS Med 2(8):e240 